\title{
8
}
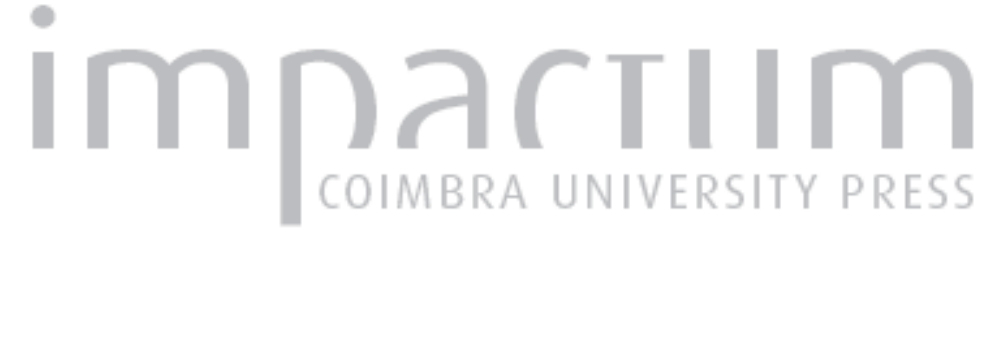

\section{A Concordata celebrada entre Portugal e a Santa Sé no reinado de D. Dinis e a estabelecida em 2004}

Autor(es): $\quad$ Matos, Francisco da Cunha

Publicado por: $\begin{aligned} & \text { Faculdade de Letras da Universidade de Coimbra, Instituto de História } \\ & \text { Económica e Social }\end{aligned}$

URL

persistente:

URI:http://hdl.handle.net/10316.2/33496

DOI: $\quad$ DOI:http://dx.doi.org/10.14195/0870-4147_44_16

Accessed : $\quad$ 26-Apr-2023 07:50:39

A navegação consulta e descarregamento dos títulos inseridos nas Bibliotecas Digitais UC Digitalis, UC Pombalina e UC Impactum, pressupõem a aceitação plena e sem reservas dos Termos e Condições de Uso destas Bibliotecas Digitais, disponíveis em https://digitalis.uc.pt/pt-pt/termos.

Conforme exposto nos referidos Termos e Condições de Uso, o descarregamento de títulos de acesso restrito requer uma licença válida de autorização devendo o utilizador aceder ao(s) documento(s) a partir de um endereço de IP da instituição detentora da supramencionada licença.

Ao utilizador é apenas permitido o descarregamento para uso pessoal, pelo que o emprego do(s) título(s) descarregado(s) para outro fim, designadamente comercial, carece de autorização do respetivo autor ou editor da obra.

Na medida em que todas as obras da UC Digitalis se encontram protegidas pelo Código do Direito de Autor e Direitos Conexos e demais legislação aplicável, toda a cópia, parcial ou total, deste documento, nos casos em que é legalmente admitida, deverá conter ou fazer-se acompanhar por este aviso. 


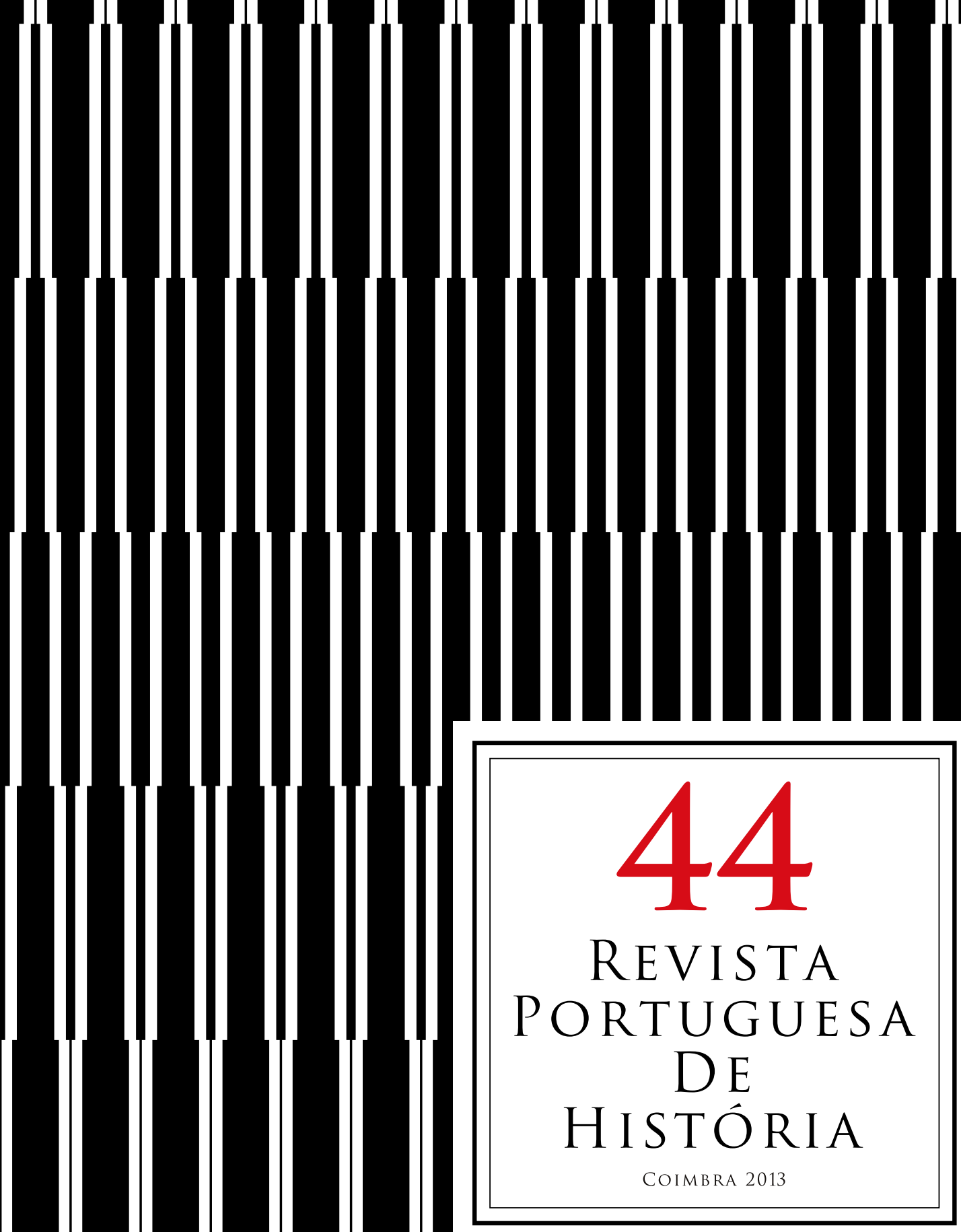




\title{
A Concordata celebrada entre Portugal e a Santa Sé no reinado de D. Dinis e a estabelecida em 2004*
}

\author{
Francisco da Cunha Matos \\ Mestre em Ciências Jurídico-Filosóficas pela Faculdade de Direito \\ da Universidade de Coimbra. \\ Assistente Convidado da Área Interdepartamental de Direito do I.P.T. \\ francisco.cunhamatos@plmj.pt
}

Resumo:

A conformação jurídica do continuum relacional entre o poder político e o religioso: da procura institucionalizada de afirmação das virtudes teologais à regulamentação dos interesses económico-sociais - a evolução antropológica.

Palavras chave:

Concordatas; Rei D. Dinis; Portugal; Santa Sé; Virtudes teologais; Interesses económico-sociais.
Abstract:

The conformation of the legal continuum relational between the political and the religious: from the demand institutionalized of the affirmation theological virtues to the regulation of economic and social interests - the evolution anthropological.

Keywords:

Concordats; King Dinis; Portugal; Holy See; Theological virtues; Economic and social interests.

* Comunicação apresentada ao "Congresso Internacional Dom Dinis: 750 anos do seu nascimento", realizado na Sociedade de Geografia de Lisboa, a 6 de Outubro de 2011, tendo-se omitido as fórmulas de circunstância e expurgado o texto de uma introdução e de um capítulo sobre a teoria do poder, em virtude da limitação de caracteres. 
"Nós estamos a caminho de uma ditadura do relativismo que não reconhece nada como definitivo e tem como valor máximo o ego e os desejos individuais".

Cardeal J. Ratzinger ${ }^{1}$

\section{O contexto político-social das relações entre Portugal e a Santa Sé: da necessidade de um acordo à reduzida efectividade das virtudes teologais}

Embora esta nossa reflexão se centre no vector religioso da política internacional levada a cabo por D. Dinis, fundamentalmente no período de apogeu do seu reinado (1288-1304) ${ }^{2}$, entendemos ser pertinente uma brevíssima analepse do reinado de D. Afonso III pragmaticamente orientada para a caracterização da situação política das relações entre Portugal e a Santa Sé herdadas pelo seu sucessor.

De facto, como sabemos, desde os seus primórdios, o reinado de D. Afonso III foi fortemente condicionado pelas relações com o papado, uma vez que este sucede, como defensor e governador do reino, a seu irmão D. Sancho II, ex vi da sua deposição, no Concílio de Lyon, alegando-se que o Capelo não aplicava a justiça, nem conseguia proteger os seus súbditos e os clérigos da turbulência social que então se fazia sentir ${ }^{3}$.

Para que tal passividade não se repetisse, ainda antes da sua entronização, D. Afonso tem de se submeter ao Juramento de Paris ${ }^{4}$, vinculando-se às exigências da Santa Sé, expressas em 14 artigos, com o intuito de se fazer cumprir a justiça no reino e de se combater a anarquia que imperava. Contudo, para fazer face às perturbações sociais, o rei desenvolve esforços no sentido de promover um processo de centralização política que, inevitavelmente, conflitua com as pretensões eclesiásticas de perpetuação da sua supremacia. Portanto, em 1268, em Roma, onde ficam como "refugiados políticos", os prelados

1 Frase proferida um dia antes de ser eleito Papa (http://paxprofundis.org/livros/bentoxvi/ bxvi.htm).

2 Segundo a sistematização cronológica adoptada por José Augusto de Sotto Mayor Pizarro, D. Dinis, Círculo de Leitores, 2005, p. 96-160.

3 Leontina Ventura, A Nobreza de Corte de D. Afonso III, Coimbra, 1992.

4 Para uma análise mais pormenorizada deste documento vide Cassiano Malacarne, A prática do Direito no Direito Adversário: as infracções institucionais de D. Dinis às leis canónicas (1279-1325), Porto Alegre, polic., 2008, p. 99, e Maria Alegria Fernandes Marques, "Poder Real e Igreja em Portugal no Século XIII: Contributo do Vaticano", in Anos 90: Revista do programa de Pós-Graduação em História, nº 16, 2001, p. 186-187. 
apresentam 43 artigos exemplificativos das infracções cometidas pelo monarca em prejuízo do foro eclesiástico, inaugurando um período de grande tensão entre o reino e a Santa Sé que conduz ao ultimato, em 1275, já no pontificado de Gregório X, expedido na bula "De regno Portugaliae", impondo a D. Afonso III a reparação dos danos provocados ao clero, no prazo de três meses ou, em caso da sua morte, de o seu sucessor o fazer no período de um ano. No entanto, o rei não cumpre o preceituado e, cinco meses mais tarde, é excomungado e o reino interdito. Um ano depois, adoece gravemente e, cerca de vinte dias antes de falecer, promete, com a aprovação do herdeiro, reparar os danos causados à Igreja, evitando morrer excomungado.

Assim, em Fevereiro de 1279, D. Dinis herda um reino interdito e um episcopado, na sua grande maioria, com ele incompatibilizado. Apesar da situação política do clero ser mais débil que nos primórdios do séc. XIII, a sua influência ainda era intensa e a sua superioridade intelectual, como refere Fortunato de Almeida, "fez com que todos aqueles que mais se distinguiam pelos seus talentos fossem aproveitados para o exercício dos cargos mais importantes, como os de embaixadores, plenipotenciários, chanceleres-mores, regedores da Suplicação, governadores da Casa do Cível, juízes, notários, procuradores e tesoureiros" ". Além disso, a própria Santa Sé reconhecia os méritos dos prelados portugueses, encontrando-se na Cúria os bispos D. Martinho de Braga, D. Egas de Coimbra, D. Mateus II de Viseu, D. Mateus de Lisboa, D. Vicente do Porto e D. Rodrigo da Guarda ${ }^{6}$.

Dada esta preponderância dos eclesiásticos, afigurava-se necessário um acordo entre Portugal e o Papado. Coube, pois, a D. Dinis o retomar do normal relacionamento entre o poder régio e o episcopal, bem como o levantamento do interdito. Para a obtenção destes objectivos, estabeleceu uma concordata (1289) e duas concórdias (1292 e 1309) ${ }^{7}$, sendo aquela o objecto central da

5 Fortunato de Almeida, História da Igreja em Portugal, vol. I, Edição preparada e dirigida por Damião Peres, Porto, Portucalense Editora, 1930, p. 157.

6 Maria Alegria Fernandes Marques, O Papado e Portugal no tempo de D. Afonso III (1245-1279), Coimbra, polic., 1990, p. 390.

7 Embora as noções de concordata e de concórdia e a sua respectiva utilização seja controvertida, cremos ser mais rigorosa a explicação terminológica de Almeida Costa em que as concordatas resultam das negociações entre o rei e as autoridades eclesiásticas com a intervenção do Papa, enquanto por concórdias se deviam entender os acordos estabelecidos entre o monarca e os representantes do clero nacional. Para mais desenvolvimentos vide Mário Júlio de Almeida Costa, História do Direito Português, 2005, p. 194; António Domingues Sousa Costa, "Concordata", in Dicionário de História de Portugal e "As Concordatas Portuguesas" in Revista Itinerarium, 1966, p. 24-46; e A. Leite, "Concordatas", in Dicionário de História Religiosa de Portugal, 1971. 
comparação sobre a qual, neste ensejo, pretendemos reflectir, consubstanciando um aparentemente pacífico período de relacionamento com a Santa Sé. Contudo, pensamos, com Hermínia Vilar, que estes acordos são, apenas, os vértices mais visíveis de um processo cujo desenlace se forjou, em grande medida, "nos bastidores da Cúria Papal, da Corte e dos Cabidos diocesanos", assistindo-se a uma fraca efectividade das virtudes teologais em face da preponderância dos estratégicos interesses político-sociais.

Com efeito, verifica-se que o modus agendi das autoridades eclesiásticas, apesar de extremamente complexo e permeável a golpes palacianos, na luta pela liberdade da Igreja, procura nortear-se por uma prática político-diplomática moderada pela Fé, Esperança e Caridade ${ }^{9}$, enquanto manifestações concretas de um monismo simples da virtude que encontra a sua finalidade fora de si mesma, na vida divina. Pugnando por um ideal de bem comum que pode ser transcendente ou imanente, sendo o primeiro o próprio Deus, como bem supremo para as almas, obtido directamente da Igreja e indirectamente extraído da sociedade civil, e o segundo a Paz, entendida como ordenada concórdia ${ }^{10}$, que é patente nas queixas do episcopado ${ }^{11}$, incluídas no articulado da Concordata de 1289.

8 Hermínia Vilar, "O Episcopado do tempo de D. Dinis: trajectos pessoais e carreiras eclesiásticas (1279-1325)”, Arquipélago. História, 2a série, V (2001), p. 582.

9 Exemplificativo da dificuldade de compatibilização das virtudes teologais com as virtudes aristotélicas é o conflito que opôs Henrique II, de Inglaterra, e Tomas Becket (1118-1170), arcebispo de Cantuária (1162-1170), "o primeiro, responsável pela institucionalização de um sistema justo e imparcial de tribunais e funcionários; o segundo, eclesiástico empenhado na afirmação do poder episcopal". Quando se defrontaram, tiveram que se reconhecer, mutuamente, não só como seres dotados de vontade individual, mas também como indivíduos titulares de papéis de autoridade: Becket assumiu a sua dívida para com o soberano e, na impossibilidade de a saldar, adoptou a posição de quem está prestes a ser martirizado. Tal acto fez estremecer o poder secular, no entanto, Henrique II não se eximiu às suas funções e mandou executar Becket, tendo, posteriormente, cumprido jejum e sido açoitado publicamente por monges, em Cantuária, para se reconciliar com o Papa. Para uma análise sistemática da noção teológica de virtudes vide MacIntyre, After Virtue, 1984, p. 165-180 e Francisco da Cunha Matos, A Societas Comunitária (De uma concepção antropológico-jurídica do Homo Humanus Virtuoso à sua singularidade étnico-genealógica e universalidade cívico-territorial, num horizonte democrático), dissertação de Mestrado em Ciências Jurídico-Filosóficas, Coimbra, Faculdade de Direito da Universidade de Coimbra, 2011, p. 26-29.

${ }^{10}$ D. Egas de Viseu, Summa de Libertate Ecclesiastica, apud Antonio Garcia y Garcia, Estudios sobre la Canonistica Portuguesa Medieval, 1976, p. 219-281.

${ }^{11}$ Quanto à realização e incrementação da Fé e da vivência e prática da Caridade, atente-se nos artigos X e XIII da Concordata de 1289 que consagram a construção de hospitais e albergarias para os pobres, sob jurisdição dos bispos, a defesa e protecção dos cristãos e o direito de asilo. No artigo XXXVIII, quase em conclusão, ordena-se que o rei se abstenha de violar a liberdade da Igreja, pois quem contra ela atentar "quebranta a grande fortaleza, na qual está a Fé Católica 
No reinado de D. Dinis, o processo de eleições episcopais, os frequentes conflitos $^{12}$ travados no interior dos cabidos, com reiterados apelos à intervenção papal, atestam a importância que estas designações assumiam para todos os poderes intervenientes. Desde a nomeação de um bispo à de um arcebispo, esta não se discutia apenas através da auscultação de um cabido, mas alargava-se às elites locais e regionais, cujas famílias nobres monopolizavam uma teia de influências extremamente eficaz, fruto da proveniência de alguns membros proeminentes do clero capitular, e até mesmo ao poder papal, preocupado em recompensar bispos e cónegos de dioceses não nacionais ou em superar conflitos emergentes no interior das dioceses. Como refere Hermínia Vilar, "O episcopado dos tempos dionisinos resulta, um pouco, de todo este jogo de equilíbrios entre poderes"13. Assim, apesar de não haver estudos monográficos exaustivos que apresentem em concreto a análise dos eclesiásticos eleitos e nomeados, parece-nos possível concluir que existe um grau de proximidade entre muitos dos clérigos nomeados para o episcopado e o rei. Este, paulatinamente, conseguiu superar as incompatibilidades herdadas, procedendo ao reforço da autoridade régia, instrumentalizando os eclesiásticos que reconheciam tacitamente o princípio da supremacia do rei, de modo a facilitarem o cumprimento das medidas que concretizavam essa supremacia. São exemplos desta habilidade estratégica, "o grupo que parece ter liderado em Roma o processo de estabelecimento das Concordatas, constituído pelo arcebispo de Braga, D. Telo, por D. Aimerico de Coimbra, D. João de Lamego e D. Bartolomeu de Silves, e com excepção deste último, é todo ele formado por eclesiásticos que ascenderam ao cargo episcopal entre 1279, no caso dos dois primeiros, e 1285, no caso do prelado de Lamego" 14 .

Apresentada a facticidade conformadora da celebração da Concordata de 1289 procedemos à sua análise, pois não nos é permitido, por imperiosas limitações de espaço, fazermos uma sumária referência à tipificação dogmática da concepção medieval de poder e sua repercussão nas relações do Estado com a Igreja e ao perfil antropológico-jurídico do medievo.

à qual a terra do rei está destinada". Destarte, evite de se "apoderar das coisas Santas, pois foi para a defender e fazer justiça que o dador e distribuidor de todos os Reinos, o cingiu com a espada temporal". Por isso, que "se abstenha de causar danos e perseguições a pessoas, que estão ao serviço do seu Povo e que Deus lhe confiou, para honra do seu Nome".

12 José Antunes, António Resende de Oliveira e João Gouveia Monteiro, "Conflitos políticos no Reino de Portugal entre a Reconquista e a Expansão", in Revista de História das Ideias, $\mathrm{n}^{\circ}$ 6, 1984, p. 113-121.

${ }^{13}$ Vilar, op. cit., p. 583.

${ }^{14}$ Idem, ibidem, p. 586, e vide Miguel de Oliveira, História Eclesiástica de Portugal, 1968,p. 15. 
Não podemos, porém, deixar de assinalar que a explicação transcendente do poder é a que faz remontar a sua origem a Deus, exprimindo-se na frase de S. Paulo, "Omnis potestas a Deo", em que o Estado e o direito são realizações humanas da vontade divina e o detentor do poder é mandatário de Deus, revestido por um pactum subjectionis que legitimava uma concepção unitária ${ }^{15}$ Igreja-Estado, na qual era o ser cristão que regulava todas as acções do homem e a Igreja estava presente em todas as esferas de acção, assistindo-se a uma secularização da Igreja e a uma clericalização do Estado, consubstanciada na sagração dos monarcas e na afirmação de uma monarquia racional e absoluta assente numa base mística, segundo a teoria teocrática do $\operatorname{poder}^{16} \mathrm{de} \mathrm{S}$. Tomás de Aquino.

\section{A Concordata de 1289: processo negocial, artigos constitutivos e contributo para o continuum relacional com a hodierna concordata}

\subsection{Processo negocial}

Traçado o contexto político-social herdado por D. Dinis, expomos resumidamente o processo negocial encetado por este monarca que culminou com a celebração da Concordata de $1289^{17}$.

${ }^{15}$ Malacarne, op. cit., p. 25.

${ }^{16}$ Embora ultrapasse os horizontes da nossa investigação, importa referir que trabalhos mais recentes recusam, liminarmente, a existência de uma teocracia medieval, entendendo que o que esteve em vigor foi uma autêntica hierocracia. Assim, em sua opinião e ancorados nas magistrais caracterizações de Marcel Prélot de hierocracia, enquanto "doutrina ou regime político, segundo o qual determinados homens consagrados a Deus pelo sacramento da Ordem exercem sobre os outros homens, por instituição divina, um poder mais eminente que possa existir" e de teocracia, como "governo directo ou indirecto do próprio Deus, pressupondo uma intervenção sobrenatural constante", só em Israel, na época do Antigo Testamento, se governou teocraticamente, caracterizando-se a época patriarcal por um monismo consubstanciado na concentração do poder espiritual e temporal na mesma pessoa, sucedendo-lhe um cesaropapismo, no período do Império Romano cristão, predominando o controlo do poder eclesiástico sobre o secular, numa hierocracia medieval, imperando a teocracia regalista na Idade Moderna, tendendo-se para um regime de separação entre a Igreja e o Estado, a partir da Revolução Francesa. Para mais desenvolvimentos vide Sérgio Ricardo Strefling, Igreja e Poder. Plenitude do Poder e Soberania Popular em Marsílio de Pádua, 2002, p. 18; António Garcia y Garcia, "Sacerdócio, Império y Reinos", Cuadernos informativos de derecho histórico, processal y de la navigación, 2, 1987,p. 499-552; Idem, "La teoria de la potestas pontificia in temporalibus durante el Medievo", (Separata) de El Tratado de Tordesillas y su época. Congresso Internacional de História, V Centenário do Tratado de Tordesillas, Junta de Castilla y León.

${ }^{17}$ Sobre as negociações estabelecidas entre D. Dinis e o episcopado vide Fernando Félix Lopes, A propósito do Conflito entre a Igreja e Portugal no tempo de D. Dinis, Separata de Estu- 
Em Setembro de 1281, na Guarda, D. Dinis reuniu-se com alguns bispos para discutir as circunstâncias que originaram a excomunhão de D. Afonso III e a interdição do reino ${ }^{18}$, resultando deste encontro um acordo que foi enviado, no ano seguinte, ao Papa. Martinho IV responde, apenas em 1284, no sentido da reprovação do texto enviado, sugerindo bastantes emendas que o rei e o episcopado deveriam aceitar. No ano seguinte, nas Cortes de Lisboa, o monarca apresentou as exigências papais mas, como entretanto Martinho IV morrera, entendeu-se que as suas determinações deixavam de ter efeito. No curto pontificado de Honório IV (1285-1288), apenas houve a oportunidade de nomeação de procuradores régios para, em Roma, conduzirem as negociações, tendo aquele pontífice criado uma comissão de três cardeais para tratarem de matéria tão complexa, mas pouco tempo depois o papa falecia ${ }^{19}$.

Só no pontificado seguinte, de Nicolau IV (1288-1292), é que a resolução final avançou. O novo papa era franciscano e tinha boas relações com o arcebispo de Braga, o também franciscano D. Telo ${ }^{20}$. Este prelado, juntamente com os já referidos bispos de Coimbra, de Silves e de Lamego, por um lado, e os procuradores régios Martim Peres, chantre de Évora, e João Martins, cónego de Coimbra, por outro, reuniram-se na Basílica de Santa Maria Maior. Aí, a 12 de Fevereiro de 1289, foi aceite e assinado por ambas as partes um acordo contemplando os 40 artigos e que ficou conhecido como sendo a primeira concordata entre o reino de Portugal e a Santa Sé, tendo sido aprovada pelo papa, a 7 de Março, pela bula "Occurrit nostrae considerationis" e remetido a D. Dinis pela bula "Cum olim inter praelatos". A par daqueles 40 artigos,

dos Teológicos. Actas da III Semana Portuguesa de Teologia (1963), 1964, p. 8-13. Para uma mais pormenorizada análise do episcopado do reinado de D. Dinis vide Maria Helena Cruz Coelho, "O Arcebispo D. Gonçalo Pereira. Um querer, um agir", in IX Centenário da Dedicação da Sé de Braga. Congresso Internacional. Actas, 1990, p. 389-462; José Augusto Ferreira, Fastos Episcopaes da Igreja Primacial de Braga, 1935; D. Rodrigo da Cunha, Catálogo e História dos Bispos do Porto, 1643; Idem, História Eclesiástica dos arcebispos de Braga, 1634; Idem, História Eclesiástica da Igreja de Lisboa, 1842; e Cartularium Universitatis Portugalensis 1288-1377, vol. I, 1966, p. 19-28.

${ }^{18}$ Sobre as relações diplomáticas entre Portugal e a Santa Sé, vide Joaquim dos Santos Abranches, Fontes do Direito Ecclesiástico Portuguez. Summa do Bullario Portuguez, 1895, e Visconde de Santarém (org.), Quadro Elementar das Relações Políticas e Diplomáticas de Portugal, 1864.

${ }_{19}$ Para uma mais detalhada enumeração dos factos negociais vide Pizarro, op. cit., p. 102, e Almeida, op. cit., p. 200-202.

${ }^{20}$ António Domingues Sousa Costa, "D. Frei Telo, arcebispo primaz, e as concordatas de D. Dinis", in IX Centenário..., cit., vol. II/I, A Catedral de Braga na História e na Arte (Séculos XII-XIX), 1990, p. 283-316. 
foram ainda aprovados mais 11 disposições entre os bispos e os procuradores régios, que o papa aceitou sem bula de aprovação e que D. Dinis também ratificou. Afere-se a importância destes textos pelo facto de terem sido assumidos como uma verdadeira concordata e de terem sido inseridos em textos legais posteriores, como aconteceu com as Ordenações Afonsinas.

\subsection{O articulado da Concordata de 1289 e os onze artigos realizados em separado}

Da análise cuidada dos textos destes instrumentos jurídicos, verifica-se que, tanto os 40 artigos da Concordata de 1289 como os restantes 11 artigos, se referem a situações ocorridas no reinado de D. Afonso III.

Do ponto de vista formal, é curioso referir, com Malacarne ${ }^{21}$, que, através do modus de redacção, é possível distinguir os artigos apresentados a Clemente IV (1265-1268) e aqueles que foram pleiteados perante Gregório X (1271-1276). De Clemente IV são os primeiros 29 artigos dos Quarenta, além dos iniciais 8 artigos dos onze, sendo os restantes do pontificado de Gregório X. Aqueles que provieram do tempo de Clemente IV invocam o rei na terceira pessoa, enquanto que nos que foram efectuados na época de Gregório X. Este dirige-se directamente ao soberano ${ }^{22}$. Encontrando-se os artigos formulados em parágrafos únicos, logo abaixo deles surge a resposta dada pelo rei através dos seus procuradores que, para defenderem aquele monarca, utilizam a eficaz estratégia argumentativa de responsabilizar D. Afonso III pelas infracções alegadas pela Santa Sé ${ }^{23}$. Além disto, constatase que não se mencionam passagens directas e explícitas do Direito Canónico, nem por invocação da Igreja nem do rei, uma vez que são recorrentes as referências ao direito comum sem, contudo, ser mencionada a fonte de onde foram retiradas, pensando-se que tal omissão se justifica pelo facto de as violências perpetradas contra a Igreja serem universalmente consideradas como desrespeitadoras de libertas ecclesiae, pois, sendo os direitos do clero unanimemente conhecidos e aceites, será desnecessária uma maior pormenorização legal. Finalmente, também porque as queixas desta Concordata dizem mais respeito às infracções cometidas pelo antecessor de D. Dinis, as demais Concórdias de 1292 e de 1309 não têm a mesma preponderância, pois

\footnotetext{
${ }^{21}$ Malacarne, op. cit., p. 163.

${ }^{22}$ Nuno Espinosa Gomes da Silva e Maria Teresa Campos Rodrigues, Livro de Leis e Posturas, Lisboa, Faculdade de Direito da Universidade de Lisboa, 1971, p. 353.

${ }^{23}$ Idem, ibidem, p. 342.
} 
não exigiram a intervenção papal e serviram, principalmente, para aferir o cumprimento dos artigos fixados em 1289.

De uma perspectiva material, embora seja impossível estabelecer uma divisão estanque dos assuntos legislados, parece-nos que a Concordata de 1289 se pode organizar em 5 partes substanciais: na primeira, do artigo I ao XII, reconhecem-se os privilégios do foro eclesiástico, da possibilidade de excomunhão e de interdição de determinados lugares e igrejas, da autonomia dos clérigos na administração dos edifícios religiosos; na segunda parte, constituída pelo artigo XIII, consagra o direito de asilo daqueles "Mouros e per Judeus / ou per christãaos" 24 que se refugiavam nas igrejas para se escaparem à justiça régia; na terceira parte, do artigo XIV ao XIX, procura-se harmonizar a jurisdição régia com a eclesiástica através da afirmação do exercício do poder judicial e de mecanismos de reacção aos abusos dos oficiais régios; na quarta parte, compreendida entre os artigos XX e XXVIII, referem-se os procedimentos de efectivação do direito de padroado, sendo evidente a vontade do rei em manter a interferência dos indivíduos laicos na organização financeira e administrativa dos templos e, sobretudo, em perpetuar o controlo da nomeação de sacerdotes; finalmente, na quinta parte, do artigo XXIX ao XL, encontram-se as disposições atinentes aos testamentos, aos bens patrimoniais do clero e à isenção de serviços públicos dos clérigos e seus dependentes.

Por seu turno, nos onze artigos efectuados em separado, o rei contesta com maior veemência as exigências dos prelados, citando costumes do reino ou a preeminência dos príncipes, fundamentado no direito romano, embora não lhe faça qualquer referência explícita. A estratégia argumentativa com que responde aos artigos, colocando as queixas da Concordata como pertencentes inteiramente ao seu reinado, de modo a que as respostas sejam o menos prejudiciais possível. Em termos substanciais, podemos agrupar estes artigos em duas partes: aquela que compreende os oito primeiros, em que se abordam as questões relacionadas como o pagamento da dízima, da aquisição de bens por parte dos clérigos, as sanções aplicadas aos roubos dos mosteiros, descoberta de tesouros, pagamento de portagens e disposições testamentárias; e uma outra composta pelos restantes três, referentes à jurisdição eclesiástica e às excepções às imunidades fiscais do clero.

Assim, verificamos que a dificuldade em chegar a um acordo denota perfeitamente a gravidade e os obstáculos que foi necessário ultrapassar, uma vez que estavam em causa interesses dificilmente conciliáveis que envolviam não

${ }^{24}$ Idem, ibidem, p. 346. 
só o rei e os seus funcionários, mas também a população e as autoridades dos concelhos. Portanto, importa salientar, com Gama Barros, que "O triunfo que a classe eclesiástica obteve nas duas composições foi mais aparente que real, como o atestam as queixas que se repetiram neste mesmo reinado de D. Dinis e nos seguintes" 25 .

\subsection{As Concórdias de 1292 e de 1309: breve alusão}

Embora tenhamos limitado o objecto da nossa reflexão à Concordata de 1289 e aos onze artigos realizados em separado, antes de procedermos à identificação de dois aspectos jurídicos que entendemos ser da maior relevância para o continuum relacional que descortinamos em relação à hodierna Concordata de 2004, impõe-se uma breve alusão a estes documentos que, ainda no reinado de D. Dinis, marcaram as relações de Portugal com a Santa Sé.

A concórdia de 1292 é a menor de todas. Apesar de tudo parecer estar já resolvido pela anterior Concordata, novas queixas surgem por parte dos prelados do Porto, Guarda, Lamego e Viseu, assumindo papel de destaque o bispo desta última cidade, D. Egas. O documento é composto por 11 artigos que unicamente contêm as resposta do rei, sendo necessário inferir quais as reclamações apresentadas. No entanto, as suas disposições permitem encerrar um ciclo de mudanças ${ }^{26}$ : tanto exógenas, no âmbito do relacionamento entre o rei e a Igreja, malgrado a virulência de algumas queixas episcopais, os conflitos entre os dois poderes nunca mais parecem atingir a dureza característica dos anteriores reinados; como endógenas, no interior do episcopado, uma vez que o elenco de prelados que tinha encabeçado a luta contra D. Afonso III será paulatinamente substituído, emergindo um novo grupo com grande proximidade a D. Dinis, fosse através do desempenho de cargos régios, fosse pelos laços pessoais tecidos.

A concórdia de 1309 foi apenas pleiteada por D. João (1293-1312), bispo de Lisboa, e pelo seu cabido. Este bispo foi um dos dois procuradores de D. Dinis que respondeu diante dos prelados, na Concordata de 1289, sendo de tal modo próximo do monarca que se pensa ter sido esse o motivo que levou o Papa a rejeitar a sua eleição para arcebispo de Braga, em $1292^{27}$. Dado o carácter predominante da Concordata, esta concórdia apresenta queixas que

${ }^{25}$ Henrique da Gama Barros, História da Administração Pública em Portugal nos Séculos XII a XV, 1945-1954, p. 128-129.

${ }^{26}$ Vilar, op. cit., p. 593.

${ }^{27}$ Malacarne, op. cit., p. 168. 
remontam àquela antecedente, sendo as respostas do rei intransigentes, citando amiúde o direito canónico para defender as suas acções, facto inovador em relação aos dois instrumentos normativos anteriores. Nas demandas, as mais das vezes, o monarca é que segue o direito canónico, enquanto o bispo extrapola, embora haja ocasiões em que os pleitos são fundamentados em leis eclesiásticas. Contudo, as infracções já tinham sido toleradas pelo Papa, em 1289, denunciando uma atitude de recusa dos artigos que os seus colegas prelados fizeram enquanto representantes do clero português com o beneplácito de Nicolau IV, sendo esta a única razão para a repetição de certas queixas em que o monarca se recusa a obedecer e o Papa tolera, uma vez que o desconhecimento de tais artigos seria impossível, visto ter sido um dos procuradores de D. Dinis, em 1289.

\subsection{O Privilégio do Foro Eclesiástico e as Imunidades Fiscais do Clero na Concordata de 1289}

Centrar-nos-emos em dois aspectos jurídico-sociais expressos na Concordata de 1289 que, ao longo dos tempos, foram mediando as relações entre Portugal e a Santa Sé, e cujas marcas são visíveis no acordo obtido no século XXI.

Aquela Concordata marcou o início do estabelecimento da harmonia entre os poderes régio e episcopal. A precedente discórdia era motivada por uma necessidade de centralização política que caracterizou os reinos europeus medievais, culminando com a emergência do absolutismo moderno. Por isso, o processo de formação do Estado Moderno é dirigido não somente contra o poder senhorial, mas ainda contra a autoridade dos bispos, atingindo-se o privilégio do foro eclesiástico e as imunidades fiscais do clero.

Com efeito, a consagração do privilégio do foro eclesiástico, em virtude do qual não só os clérigos estavam em muitas situações isentos da acção do poder civil, mas também no direito de reclamar que as suas causas fossem julgadas segundo o direito das decretais, mesmo nos casos em que deveriam responder perante a justiça secular, é uma das consequências da introdução do direito canónico em Portugal, em conformidade com o que estatuiu D. Sancho I, em carta de 1210, dirigida ao bispo, cónegos e burgueses do Porto ${ }^{28}$.

Se, inicialmente, se entendia que o clérigo demandado por coisa pertencente à Igreja, respondia sempre perante uma autoridade eclesiástica, o mesmo sucedendo nos crimes eclesiásticos, ao invés, quando se tratasse de coisa pertencente ao clero e não à Igreja, respondia perante juiz secular, tal como

\footnotetext{
${ }^{28}$ Almeida, op.cit., p. 158-159.
} 
nos restantes crimes que não fossem eclesiásticos. Contudo, no reinado de D. Afonso III, estas regras foram alteradas, pois determinou-se, por um lado, que nos crimes punidos com multa, o clérigo devia responder perante o juiz secular e, por outro lado, que se o clérigo esbulhasse o leigo de coisa da qual o segundo tinha posse de ano e dia, o esbulhado podia demandar o clérigo perante o juízo secular, exclusivamente se o fizesse num prazo de um ano e dia depois do esbulho, se o fizesse depois, o clérigo tinha o direito de só responder perante o juízo eclesiástico.

Tendo estas alterações contribuído para a decadência do privilégio do foro, D. Dinis respeitou-o unicamente nos casos em que o direito canónico expressamente o reconhecia, de maneira a garantir ao clero uma mais efectiva e constante afirmação das suas imunidades legítimas. Neste sentido, ainda antes da Concordata, em 1286, o monarca criou legislação determinando que não se procedesse à prisão por um crime de clérigo, excepto se lhe correspondesse a pena de morte ou outra pena corporal, sendo neste caso imediatamente entregue ao bispo ou ao seu vigário para que se fizesse justiça ${ }^{29}$.

Estas providências adoptadas por D. Dinis para extinguir os abusos em matéria de privilégios eclesiásticos estavam de acordo com as ideias do Pontífice, pois muitos habilitavam-se apenas com ordens menores para se darem como pertencentes à classe eclesiástica e usufruírem das vantagens que daí derivavam, como era a isenção da hoste e do fossado, da anúduva e das imposições fiscais. Consubstanciando esta lógica de combate a atitudes de instrumentalização de costumes religiosos, na Concordata de 1289, no artigo XXXV, estabelece-se um limite ao privilégio do foro. De facto, na resposta à queixa de desrespeito por este direito, os procuradores régios afirmam que "o dito Rey nom entende a chamar ou citar nem aynda Julgar alguu bispo nem clerigo sobre eygreias dereitas e cousas ecclesiasticas nem sobre possisões delas Mays praz a ele que en todas estas coussas respondam dant seu Jujz ecclesiastico" ${ }^{30}$, evidenciando o respeito da Coroa pelo privilégio do foro eclesiástico. No entanto, de seguida, impõe uma restrição: "E quanto he sobre os outros preitos que os clerigos ouuerem super possisões que laurauam regueengas. foreyras conhucudas he fecta special aueença antre prelados e os procuradores dauandictos" 31 . Tendo sido esta excepção ao "nisi forte episcopus a rege feudum teneret" extremamente controvertida, os procuradores do monarca, no artigo IX, dos onze efectuados em separado à Concordata de 1289, apresentam a seguinte

\footnotetext{
${ }^{29}$ Idem, ibidem, p. 159.

${ }^{30}$ Silva e Rodrigues, op. cit., p. 356.

${ }^{31}$ Idem, ibidem, p. 356.
} 
justificação: "Mays porque os Reys onde uem o dicto Rey ouueram de dereito sempre e de custume que também clérigos como leygos. que lauram / as possissões fiscaaes notarias ffeudatorias ou Reguengas deuem a rresponder e acustumarom. sobre taaes possisões dereitos e çenssos delas en ssa Corte ou Dante outro juiz sagral. quer elRey que esto sse faça e que esto sse aguarde também a ele como aos seus suscessores a que esta rresponsom lounam os prelados e outorgam" 32 .

Sem pretendermos analisar os argumentos que sustentam a compatibilidade desta restrição ao direito do foro nas terras reguengas e foreiras com o direito canónico $^{33}$, apresentamos esta medida de D. Dinis como tentativa audaz e inovadora não só de clarificação do âmbito de aplicação das jurisdições régia e eclesiástica, inferindo-se a supremacia do carácter vassálico das relações entre os reis e alguns bispos, capaz de quebrar legitimamente o privilégio do foro eclesiástico, mas também de superação das dúvidas emergentes dos desvios das propriedades régias, que eram doadas pela Coroa a determinados nobres e estes deixavam-nas à Igreja, relevando que apenas detinham a mera posse e não a sua efectiva propriedade.

Outro dos assuntos mais presentes nas relações entre Portugal e a Santa Sé é o das imunidades fiscais. O direito canónico limitou a obrigação de os bens eclesiásticos contribuírem para os encargos gerais, v. gr. o Concílio III de Latrão (can. 19) estabeleceu, em 1179, que aqueles bens só estavam sujeitos a imposições, perante a observância de dois requisitos: a) quando para a satisfação dos encargos não fossem suficientes as posses dos leigos; $\mathrm{e}, \mathrm{b}$ ) o reconhecimento pelo clero e pelos bispos da necessidade e utilidade das contribuições pedidas, tendo sido decretado, apenas em 1296, por Bonifácio VIII, que ao clero se não exigissem contribuições sem autorização expressa da Santa Sé.

Em Portugal, as disposições legais eram bastante díspares, facto que deu lugar a incessantes contestações. Assim, nos princípios do séc. XIII, pensa-se que as igrejas eram isentas de direitos e tributos reais, bem como as ordens religiosas, sobretudo as militares, careciam de privilégio especial para gozarem a referida isenção, pois, como refere Fortunato de Almeida, "Embora os factos nem sempre correspondessem à regra jurídica, é certo que prevaleceu o princípio da imunidade, como demonstra o próprio facto de se proibir que as

${ }^{32}$ Idem, ibidem, p. 369.

${ }^{33}$ Para mais desenvolvimentos vide Malacarne, "É atribuído aos clérigos o privilégio do foro "Nisi forte episcopus a rege feudum teneret". Um estudo sobre um casus excepti à Libertas Ecclesiae aplicado ao período do reinado de D. Dinis (1279-1325), antepassado directo de D. Pedro I do Brasil e IV de Portugal”, 2009, p. 303-312. 
igrejas ou pessoas eclesiásticas adquirissem terras reguengas, a fim de evitar que fossem diminuídos os interesses" 34 .

$\mathrm{Na}$ Concordata de 1289 existem três queixas da Igreja, reclamando sentir-se constrangida pelo rei para o pagamento de muralhas, pontes e outras obras públicas, como são exemplos os artigos IX, XI e XII. Nestas disposições faz-se referência a duas formas diferentes de contribuição. No artigo IX, a reclamação é feita sobre a cobrança indevida aplicada para a construção de muralhas que pertencem aos senhorios reais e às cidades, admitindo o monarca que devem ficar isentas desse pagamento aquelas igrejas que, pelo costume, têm tal direito, devendo todas as outras cumprir esse encargo fiscal, pretendendo-se que o direito canónico ceda ao direito consuetudinário ${ }^{35}$, à semelhança do aludido caso da citação judicial em terras reguengas, verificando-se a cobrança da anúduva sobre os rendimentos espirituais, os dízimos, o que era considerado um sacrilégio.

Diferentemente, no artigo XI, D. Dinis reconhece o direito dos prelados de forma integral. Trata-se da cobrança de talhas para a construção de muralhas nas cidades que possuem terras do rei e não nas suas terras senhoriais. Como sugere Cassiano Malacarne, a resposta favorável a este artigo ocorre mais por respeito a uma lei de D. Afonso II, que concede imunidade às terras que não são directamente utilizadas pelo monarca, do que por deferência ao direito canónico, pretendendo-se isentar os clérigos residentes em concelhos com herdades do rei. Do mesmo modo, apesar do artigo XII não referir os locais onde eram construídas as muralhas, o rei aplica o direito comum apenas se não houver privilégios ou acordos nos locais onde existissem as avenças. Assim, "as cobranças tributárias, entendidas quando se utiliza um património eclesiástico, poderiam ser efectuadas nos casos em que o costume e os privilégios estabelecidos há muito tempo assim o permitissem" 36 .

Devido à tensão resultante da dificuldade de compatibilizar a disposição dionisina, aceite por Nicolau IV, e o direito canónico, na concórdia de 1309, o bispo de Lisboa reclama sobre o mesmo tipo de tributação, neste caso, aquela que se cobra para a organização de feiras e a construção de fontes. Neste documento, fica claro o direito geralmente aceite naquele tempo, percepcionando-se que o rei pode obrigar os clérigos a pagar como os leigos para a construção de coisas honestas e pias, tendo em vista o proveito comum,

${ }^{34}$ Almeida, op.cit., p. 165.

${ }^{35}$ Invocando a communis utilitas, caracterizada em Malacarne, A prática do Direito no Direito Adversário: as infracções institucionais de D. Dinis às leis canónicas (1279-1325), p. 265 e ss.

${ }^{36}$ Idem, ibidem, p. 257. 
como as fontes, as pontes, as estradas e largos, sendo coagidos a contribuir para o bem comum pelos seus bispos que, nestes casos, não deveriam negar justiça.

\section{A Concordata de 2004}

\subsection{O processo negocial}

Em 2004, oito séculos após a celebração da concordata do reinado de D. Dinis, o Estado português estabeleceu a mais recente concordata com a Santa Sé. Na verdade, vários factores conduziram a que se tornasse inevitável a revisão da Concordata de 1940, sobretudo razões de índole social, cultural, económica e política que emergiram nas sociedades portuguesa e europeia. Desde a celebração do Concílio Ecuménico Vaticano II, às alterações políticas decorrentes da Revolução de 25 de Abril de 1974, passando pela adesão à União Europeia, pela promulgação da nova Lei da Liberdade Religiosa, que realça o princípio constitucional da igualdade de direitos entre todas as confissões religiosas e da liberdade religiosa para todos os cidadãos.

O conteúdo de certos articulados da Concordata de 1940 careciam de actualização, pois algumas normas perderam a sua vigência, uma ou outra norma fora pouco praticada, outras foram extrapoladas na sua interpretação e aplicação, sendo as áreas do ensino da religião nas escolas, o património, o direito fiscal, a missionação, as instituições sociais, aquelas que mais necessitavam de uma conveniente adequação.

O processo que ficou concluído a 18 de Maio de 2004, no Vaticano, com a assinatura do Primeiro-Ministro português por Portugal, e pelo Secretário de Estado pela Santa Sé, aprovada pela Resolução da Assembleia da República $\mathrm{n}^{\circ} 74 / 2004$, de 30 de Setembro, foi moroso, como é característico de um processo com implicações tão vastas e importantes num relacionamento multissecular, que se deseja profícuo e pacífico. Segundo o então Ministro dos Negócios Estrangeiros e das Comunidades Portuguesas, "Foi também uma negociação pautada por uma grande vontade de cooperação construtiva e por um espírito amigável e de respeito mútuo entre o Estado Português e a Igreja Católica"37. Para tal, contribui de forma decisiva a actuação dos prestigiados elementos da Comissão Negociadora da Santa Sé.

${ }^{37}$ António Monteiro, "Discurso do Ministro dos Negócios Estrangeiros e das Comunidades Portuguesas no dia da assinatura da Concordata de 2004 na Assembleia da República", consultado em http://notasformais.blogspot.com/2004_09_01_archive.html. 
O novo texto não se afasta muito do anterior em termos de estrutura, desde logo porque as matérias abrangidas correspondem, no essencial, às mesmas que tradicionalmente são objecto das relações entre qualquer Estado e a Santa Sé, surgindo as maiores inovações em sede de nomenclatura e de técnica legislativa, existindo a preocupação de modernizar o seu substrato e de o adequar aos grandes princípios constitucionais vigentes no nosso país, nomeadamente o da laicidade do Estado e o da igualdade das religiões e cultos.

Sendo de louvar a boa vontade das partes, findo o processo negocial, o Papa João Paulo II referiu que este novo acordo favorece o "bem comum da Nação", exprimindo o seu "profundo apreço pela atenção que o Governo e a Assembleia da República portuguesa demonstram em relação à missão da Igreja, culminada na hodierna assinatura"38.

\subsection{O articulado da Concordata de 2004}

Assumindo-se como pressupostos os princípios da autonomia e independência da Igreja Católica e do Estado português, reconhecendo-se não só a importância da anterior Concordata de 1940 para reforçar os laços históricos e consolidar a actividade da Igreja Católica em Portugal, em benefício dos fiéis e da comunidade portuguesa em geral, mas também da necessidade de uma actualização em virtude das profundas transformações ocorridas nos planos nacional e internacional, a Santa Sé e a República Portuguesa celebraram a actual concordata. Formalmente, ela encontra-se redigida em 33 artigos que, diferentemente de Alonso Perez ${ }^{39}$, organizamos em sete partes substanciais: a primeira, composta pelos primeiros sete artigos, nos quais se expõem considerações iniciais acerca, por exemplo, dos objectivos do documento (art. $1^{\circ}$ ), do respeito pelo direito canónico $\left(\operatorname{art} .2^{\circ}\right.$ ), reconhecimento do domingo como dia festivo $\left(\operatorname{art} .3^{\circ}\right.$ ) ou da adaptação às novas relações internacionais, afirmando-se que as disposições deste acordo não podem prejudicar as normas do direito internacional (art $4^{\circ}$ ). A segunda parte, compreendida nos artigos $8^{\circ}$ a $12^{\circ}$, introduz uma grande novidade em relação a 1940, o reconhecimento da personalidade jurídica da Conferência Episcopal Portuguesa (art. $8^{\circ}$ ), instituindo a liberdade de criação de personalidade jurídica das dioceses, paróquias e outras jurisdições

${ }^{38}$ Saturnino Gomes, “Análise ao texto da Concordata de 2004”, consultado em http://www. agencia.ecclesia.pt/cgi-bin/noticia.pl?id=8897.

${ }^{39}$ Material e sistematicamente agrupa os artigos da Concordata em oito partes (José Ignacio Alonso Perez, "Appunti per una prima lettura del Concordato del 18 maggio 2004 tra la Santa Sede e la Repubblica Portoghese", in Ius Ecclesiae, 2004, p. 523-546). 
eclesiásticas $\left(\operatorname{art.} 9^{\circ}, \mathrm{n}^{\circ} 2\right)$, mediante a inscrição em registo próprio do Estado em virtude de documento autêntico emitido pela autoridade eclesiástica competente de onde conste a sua erecção, fins, identificação, órgãos representativos e respectivas competências (art. $10^{\circ}, \mathrm{n}^{\circ} 3$ ), regendo-se a Igreja Católica e as suas instituições portuguesas através da harmonia do direito canónico com o direito português $\left(\operatorname{art} .11^{\circ}\right)$ e, caso desempenhem actividades de assistência e solidariedade, usufruem dos mesmos privilégios que as pessoas colectivas privadas com fins da mesma natureza. A terceira parte, exposta do art. $13^{\circ}$ ao art. $16^{\circ}$, preceitua as necessárias alterações ao regime do casamento, na medida em que o Estado português reconhece os efeitos civis do matrimónio católico celebrado em conformidade com as leis canónicas, desde que o respectivo assento de casamento seja transcrito para os competentes livros do registo civil (art. 13\%), fixando-se que as decisões relativas à nulidade e à dispensa pontifícia do casamento rato e não consumado pelas autoridades eclesiásticas competentes, apenas produzem efeitos civis, a requerimento de qualquer das partes, após revisão e confirmação por um competente tribunal do Estado $\left(\right.$ art. $\left.16^{\circ}\right)$. Além disso, a Santa Sé aproveitou esta ocasião para, reafirmando a doutrina da Igreja sobre a indissolubilidade do vínculo matrimonial, recordar aos cônjuges o grave dever que lhes incumbe de se não valerem da faculdade civil de requerer o divórcio ( $\operatorname{art.} 15^{\circ}, \mathrm{n}^{\mathrm{o}} 2$ ). Na quarta parte, artigos $17^{\circ}$ a $21^{\circ}$, consagra-se o livre exercício da liberdade religiosa, nas suas diversas dimensões: assistência religiosa aos membros das Forças Armadas e de segurança (art. $17^{\circ}$ ), às pessoas impossibilitadas de exercer, em condições normais, o direito de liberdade religiosa (art. 18\%), a afirmação do dever do Estado de cooperar com os pais na educação dos filhos, assegurando o ensino da disciplina de Educação Moral e Religiosa Católica, cuja frequência depende de declaração do interessado (art. 19 $)$. Consagra-se, também, o reconhecimento do direito de construir seminários e outros estabelecimentos de formação e cultura eclesiástica, bem como o direito de fundarem e orientarem escolas em todos os níveis de ensino e formação, garantindo a equivalência dos graus, títulos e diplomas obtidos nesses estabelecimentos, sem qualquer tipo de discriminação, referindo-se expressamente o caso da Universidade Católica Portuguesa (artigos $20^{\circ}$ e $21^{\circ}$ ). A quinta parte, composta pelos artigos $22^{\circ}$ a $25^{\circ}$, regula os bens patrimoniais, móveis e imóveis, da Igreja Católica, segundo um princípio de repartição de responsabilidades entre o Estado e a Santa Sé na conservação dos monumentos $\left(\operatorname{art} .22^{\circ}\right.$ ), tendo-se acordado a criação de uma comissão bilateral para o desenvolvimento da cooperação quanto a bens da Igreja que integrem o património cultural português ( $\operatorname{art} .23^{\circ}, n^{\circ} 3$ ), ficando claro que nenhum templo, edifício ou dependência afecto ao culto católico pode ser intervencionado 
sem acordo prévio com a autoridade eclesiástica competente e por motivo de urgente necessidade pública (art. $24^{\circ}, \mathrm{n}^{\circ} 1$ e art. $25^{\circ}, \mathrm{n}^{\circ} 2$ ). Na sexta parte, nos artigos $26^{\circ}$ e $27^{\circ}$, identifica-se o elenco das imunidades fiscais das autoridades eclesiásticas no que respeita aos impostos gerais, locais, regionais e de imposto de selo (art. 26 ${ }^{\circ}$ ), podendo a Conferência Episcopal exercer o direito de incluir a Igreja no sistema de percepção de receitas fiscais previsto no direito português (art. $27^{\circ}$ ). Finalmente, na sétima parte, composta pelos seis últimos artigos, encontram-se as disposições finais, sendo a norma mais importante a que regula, inovadoramente, a instituição de uma comissão paritária para o desenvolvimento do princípio da cooperação, com o intuito de procurar uma solução comum, nos casos de dificuldade de interpretação dos preceitos, e de sugerir quaisquer outras medidas tendentes à sua boa execução (art. 29%), prendendo-se os restantes com pormenores a propósito do reconhecimento dos dias de feriado religiosos (art. $30^{\circ}$ ) e de aspectos relacionados com a entrada em vigor do diploma legislativo.

\section{3. continuum relacional entre a Concordata de 1289 e a Concordata de 2004: da evolução do animus à tendencial manutenção do corpus de duas medidas estruturantes}

É interessante verificar que, apesar das grandes inovações experimentadas nas actuais relações entre Portugal e o Vaticano, sobretudo, com a formação de duas comissões paritárias, enquanto órgão de concertação permanente e potenciador do princípio da cooperação institucional, com a eliminação da intervenção estatal na nomeação dos bispos e com o reconhecimento da personalidade jurídica da Conferência Episcopal, também se descortinam continuidades com o relacionamento de Portugal com a Igreja, no reinado de D. Dinis.

De facto, se as primeiras, decorrem de uma evolução antropológica que foi eclodindo ao longo dos séculos, permitindo-nos caracterizar, diferentemente do medieval, o homem contemporâneo como pessoa, enquanto "categoria axiológica" "40 cujas dimensões de suum, assimilada pelo princípio supra-positivo de igualdade materializada numa social associabilidade, exemplarmente caricaturada na "Fábula do porco-espinho" de Shopenhauer" ${ }^{41}$, e de commune,

\footnotetext{
${ }^{40}$ A. Castanheira Neves, "A imagem do homem no universo prático", in Digesta, $1^{\circ}$ volume, Coimbra, Coimbra Editora, 1995, p. 331-336.

${ }^{41}$ Cuja moral se substancia na tolerância da proximidade dos outros apenas quando estes são necessários à nossa sobrevivência, evitando-a sempre que possível.
} 
consubstanciada no princípio supra-positivo da responsabilidade, devem ser respeitadas e prático-culturalmente realizadas, sendo esta concepção antropológica sustentadora de um hodierno Estado de Direito Democrático; as segundas, aferem-se pela tendencial manutenção temática das preocupações regulamentadas pelas partes envolvidas, como se compreende através da análise das questões de jurisdição eclesiástica e das isenções fiscais.

Como vimos, na Concordata de 1289, no artigo XXXV, D. Dinis procura clarificar os privilégios do clero em relação ao direito do foro eclesiástico, impondo-lhe a restrição de, nas terras reguengas e foreiras, o clérigo ser apresentado ao juiz secular. Em 2004, no art. $2^{\circ}$, a República Portuguesa reconhece à Igreja o direito de exercer a sua missão apostólica, sem qualquer restrição no culto, no magistério e ministério, na jurisdição eclesiástica, enquanto o art $12^{\circ}$, procura harmonizar os preceitos do direito canónico com o direito português, a propósito da identificação dos elementos normativos a aplicar às pessoas jurídicas canónicas. Do confronto destas disposições, detectamos uma significativa alteração do seu animus, enquanto espírito norteador dos preceitos, pois, ex vi do princípio da laicidade do Estado, a Concordata de 2004 concede plena liberdade religiosa, evitando tentações de intromissão estatal e o uso ilegítimo de práticas ou meios católicos, ao passo que D. Dinis pretendia, precisamente, afirmar a supremacia do poder régio sobre o poder espiritual, exercendo o seu domínio sobre o episcopado ${ }^{42}$. No entanto, a tendencial manutenção do corpus da pretensão é evidente pela continuidade da preocupação do Estado e da Santa Sé em clarificar os domínios jurídico-institucionais de aplicação da jurisdição eclesiástica, mantendo-se a segunda firme na tentativa de afirmação do direito canónico e da sua própria jurisdição.

Da mesma forma, na Concordata de 1289, nos artigos IX, XI e XII, o rei concedia imunidades fiscais aos elementos do clero, embora exigisse a sua colaboração para a construção e reparação de bens de serviço público, como as pontes, as estradas e as fontes. Na Concordata de 2004, no art. $26^{\circ}$, determina-se que a Igreja está isenta de impostos sobre os contributos dos fiéis para o culto, ofertas para a concretização de fins religiosos, distribuição gratuita de publicações com avisos ou instruções religiosas e sua afixação nos lugares destinados ao culto e, ainda, são isentos os lugares de culto ou edifícios que se destinem a fins religiosos, seminários e instituições de formação eclesiástica, ficando fora do âmbito desta imunidade não só as pessoas jurídicas canónicas, detentoras de actividades diversas das religiosas, como as de solidariedade

${ }^{42}$ Em clara oposição, o art. $2^{\circ}, \mathrm{n}^{\circ} 3$ da Concordata de 2004, refere "Os bispos e as outras autoridades eclesiásticas gozam da mesma liberdade em relação ao clero e aos fiéis". 
social, educação e cultura, além dos comerciais e lucrativos, sendo sujeitas a IRC, mas também os eclesiásticos, que se encontram obrigados ao pagamento de impostos, o que não acontecia até então ${ }^{43}$, admitindo-se, no entanto, no art. $27^{\circ}$, que a Conferência Episcopal possa aderir ao sistema de receitas fiscais previsto no direito português, implicando um acordo entre os órgãos do Estado e as autoridades eclesiásticas competentes. Mais uma vez, ao confrontarmos as normas medievais com as actuais, percebemos que ocorre uma maior responsabilização dos eclesiásticos para a criação e conservação dos bens comuns, embora seja quase inexistente a tributação do património do clero, apesar de D. Dinis se aperceber do prejuízo que essas imunidades traziam ao reino. Contudo, o corpus da medida mantém-se tendencialmente nos mesmos termos, dada a preocupação da Santa Sé em procurar garantir a situação fiscal mais confortável possível.

Assim, pela análise de confronto-debate entre as específicas disposições das Concordatas de 1289 e 2004, verificamos que o continuum relacional que delas brota se repercute ao nível do corpus substancial das preocupações institucionais e patrimoniais, sustentadoras de uma política de perpetuação do poder, evidenciadas ao longo dos séculos, em detrimento da efectivação da disciplina das virtudes teologais da Fé, Esperança e Caridade. Este facto, embora frustrante, não é surpreendente por não ser o proselitismo religioso ou político horizonte teleológico das concordatas, uma vez que estas são elaboradas para o proteger, isto é, têm como primordial finalidade a regulação das relações dos dois poderes, com o intuito de resolver pontos concretos de mútuo interesse ou, até, dissídios, distinguindo-se dos tratados internacionais por serem celebradas por sociedades distintas, soberanas na respectiva ordem, mas que exercem autoridade sobre os mesmos súbditos ${ }^{44}$.

\section{Considerações Finais}

Chegados a este momento, cremos ser pertinente tecer algumas considerações conclusivas e expressar um desejo.

Como pensamos resultar do exposto, no reinado de D. Dinis, monarca responsável por uma situação de desafogo e crescimento económicos ${ }^{45}$ propul-

${ }^{43}$ Como salienta Saturnino Gomes, "No art. $8^{\circ}$ da C1940 estipulava-se: «... de igual isenção gozam os eclesiásticos pelo exercício do seu múnus espiritual»” (Gomes, op. cit., p. 7).

${ }^{44}$ Para mais desenvolvimentos vide A. Leite, op. cit..

${ }^{45}$ Para uma mais aprofundada análise económica do reinado de D. Dinis, vide Pizarro, op. cit., p. 129-131. 
sionado por uma rigorosa e estratégica política de aforamentos, uma dinâmica exploração de minas, fomento e criação de feiras potenciadoras da exportação de matérias-primas e de produtos alimentares, a celebração da Concordata de 1289 foi um poderoso instrumento ao serviço da centralização administrativa e de conciliação do poder régio com a Santa Sé, concretizando-se na intervenção do rei nas nomeações de alguns bispos que, apesar desta se manter ao nível do não visível, ou seja, da acção que não transparece na documentação que essas eleições e nomeações originavam, a verdade é que os resultados obtidos e os conflitos que rodearam alguns desses momentos parecem-nos ser provas cabais dessa intervenção. Portanto, concluímos que este acordo pontifício expressa não só um Papado menos interessado em impor uma supremacia espiritual do que uma partilha de competências, mas também um episcopado, inevitavelmente, mais sujeito à pressão régia.

No que tange à Concordata de 2004, verificamos que se trata de um documento adaptado à realidade actual da vida da Igreja e de Portugal, enquanto membro da União Europeia, dinamizador do princípio da cooperação, que reforça com maior veemência as relações entre as duas instituições, entretecendo um diálogo entre a Santa Sé e Portugal para a salvaguarda das suas autonomias e do bem dos cidadãos. No entanto, apesar destes consideráveis avanços civilizacionais, mobilizadores de um animus renovado, salientamos a singular continuidade do corpus das preocupações institucionais e patrimoniais que nos permitem concluir que a Igreja, nas relações com os Estados, em favor da sua organização político-administrativa, negligencia a efectivação de uma doutrina de disciplina intersubjectiva das virtudes teologais.

Assim, para terminar, não sob a crueldade da agonia de tântalo nem com exacerbado optimismo, formulamos o desejo que de iure condendo regulador das relações entre Estados e a Santa Sé seja mais axiológico que orgânico-institucional, instituindo medidas normativas de reconhecimento dos católicos como homines humanus do direito ${ }^{46}$, reciprocamente reconhecidos como pessoas, capazes de, intra-intersubjectivamente, mobilizar as virtudes teologais da Fé, da Esperança e da Caridade.

Recebido em/Text submitted on: 21/01/13

Aceite em/Approved on: 17/07/13

\footnotetext{
${ }^{46}$ No sentido apresentado em José Manuel Aroso Linhares, "Humanitas, Singularidade Étnico-Genealógica e Universalidade Cívico-Territorial. O «pormenor» do direito na «ideia» da Europa das Nações: um diálogo com o narrativismo comunitarista”, in Revista Xurídica da Universidade de Santiago de Compostela, 2006, p. 60-64.
} 